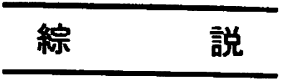

\title{
気道異物最近の傾向について
}

*瀧 野 賢 一

\section{Recent Trends of Foreign Bodies in the Trachea and Bronchi}

\author{
Kenichi Takino, M.D.
}

St. Luke's International Hospital

A search for cases of fcreign bodies in the trachea and bronchi in literature after 1970 revealed a total of 166 cases.

The author analized these cases as well as his own cases and confirmed that the Holzknecht's sign is a reliable criterion for diagnosis of a foreign body in the lower airway although the sign is not always prominent in every case. The review of the literature also indicated that foreign bcdies in infants, iatrcgenic and radiolucent foreign bodies appear to be of major interest to otolaryngologists. Indication for tracheotomy in removal of foreign bodies and for ventilating bronchoscopy is discussed.

The author pointed to the recent increasing trend of choice of flexible bronchoscopy for removal of foreign bcdies and concluded that further development of the techniques in this field could be achieved by learning various difficulties that were experienced by our predecessors who used only hard bronchoscopes.

気道異物に関する最近の傾向を把握するため, 1970 年以降の内外文献, 報告166件（内116, 外50）を通覧 し, それを統計, 一般, 治療, 症例報告に大別し（表 1 )，それに自験例を併せて検討し考察してみた。

\section{1. 統計}

内外の統計的観察20件中，一般統計は 9 件である

表 1 国内外文献（1970 76)

\begin{tabular}{|c|c|c|c|}
\hline & 国内 & 国 & 計 \\
\hline 統 & 12 & 8 & 20 \\
\hline 一 般 (論説) & 19 & 5 & 24 \\
\hline 断 & 6 & 4 & 10 \\
\hline 療 & 19 & 14 & 33 \\
\hline 例 & 60 & 19 & 79 \\
\hline 合 & 116 & 50 & 166 \\
\hline
\end{tabular}

* 聖路加国際病院・気管食道科
が，その他は幼小児気道異物を対象とした統計 6 件を はじめとし, 医原性異物, X線透過性異物, 麻酔科か らの気道異物統計など，それぞれ問題点をとらえての 統計的観察を行っている。

また個々の症例報告79件についてみると，看過異物 30 , 医原性異物 17 , 尖鋭異物 $12, \mathrm{X}$ 線透過性異物 11 , その他 9 となっている。これらの数值は気道異物の最 近の傾向を示しているように思われる。

また, これらの統計や症例報告に小児科, 内科, 胸 部外科, 麻酔科, 放射線科など関係各科からの報告が 散見されるのも, 最近の傾向とみることができる。気 道異物が耳鼻科医だけでなく, 関係各科から角度を変 えての考察，検討は歓迎す心゙き傾向である。

一般統計では年齡, 性別, 異物の種類, 頻度などに 特に従来と変ったところはないようだが，気道異物の 介在部位について, 乳幼児では右気管支より左気管支 に異物が多くみら机たとする報告1)がある。これは Link 教授（1964）の乳幼児気道異物は左気管支に多 いとする説（気管 4 , 気管分岐部 2 , 右気管支 10 , 左 
気管支28）に合致するものである。私の 2 才以下 19 例 （気管 2 , 右気管支 8 , 左気管支 9 ）では，左右特に 違いはないが, 徉来の説のように右に多くはない。 Link のい5，乳児では左右気管支の 分岐角度は左右 とも約55度で差はなく，しかも乳幼児は右手にものを 持ち, 左下りの臥位をとることが多いためとする説を 確かめるためにも，乳幼児の気道異物を年齡別に調查 してみる必要があると思う。

\section{2. 診 断}

診断に関する内外文献, 症例報告をみると, 初診 時, 慎重に法に従い諸検査をすすめれば，異物診断は 困難ではないとしながらも，依然としてピーナッッや プラスチック製品などX線透過性異物が看過され，気 管支炎とか喘息として治療されていることが多い。

ところで，これらのX線透過性異物の診断に，吸気 時, 呼気時の胸部X線写真をとり, 比較して診断する 必要のあることを強調している報告が散見される。 Holzknecht の sign がようやく小児科, 内科, 初診医 に注目されるようになったのであるが，この Holzk.

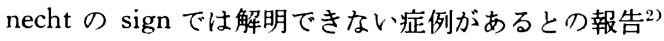
がある。

Holzknecht の sign（以下 H. sign と略す）は 1899 年に放射線科医である G. Holzknecht が右気管支に 狭窄のある24才の男の胸部X線透視検査中に, 縦隔, 心臓の陰影が吸気時に移動する病的現象を発見し，発 表したものである゙”。彼はこの病的現象を種々検討し た結果, 縌隔心臓陰影が吸気時に移動する側が患側 で，横隔膜の動きも健側に比して悪い，この病的現象 は静かな呼吸運動では認められないが, 深呼吸をさ せ, 深吸気時と呼気を出しきった深呼気時の透視所見 を比較すれば判るとし，気管支異物による気管支狭窄 の場台にも，この現象は認められると附言している。

従って Holzknecht は, 気道異物の介在部位, 状況 によって起こる胸部X線写真の種々相を,このH.sign で解明しているわけではない。気道異物の診断にこの H. sign が用いられるようになったのは後日のことで ある。そこで, 異物による胸部X線所見の読み方如何 によっては, H. sign では解明し得ない, 解明し難い 場合もありうることになる。

この点に関し Kassay4) は気道異物によって起こる 胸部X線所見の種々相を (1) Simple Stenosis. (2) Valvular Emphysema (3) Atelectasis の3 型に分類し, それを H. signでわかり易く解明している。すなわ ち, 上記 3 型何れの場合でも, 深吸気時と深呼気時の
胸部X線写真を撮り，比較すれば，深吸気時に縦隔， 心炡陰影が移動する側が患側であるとした。例えば異 物による 1 側の Atelectasis で, 緃隔, 心臟陰影が患 側に偏在している場合でも, 深呼気時には縦隔, 心臓 は少し反対側に寄るように動くが, 深吸気時には健側 肺のふくらみに押されて元の偏在位に戻る。そこで異 物介在側は吸気時に移動した側, Atelectasisのある側 と判定される。私も自分の症例についてこの方法で判 定してみたが, この H. sign そのものによる患側の判 定で正しく迷うことなく診断し得た。

何れにせよ, 気道異物のX線診断には必す深呼吸時 の吸気, 呼気の胸部X線写真を撮り, 比較することが 必要である。1枚の胸部X線写真で診断できるのは, $\mathrm{X}$ 線非透過性異物の場合だけであることを忘れてはな らない。

他に, 透過性異物の診断に斎藤ら 末を異物に吹きつけ, X線透視, 写真に異物を造影 し, その介在部位, 状況を明らかにする方法を発表し た。この造影法はX線透視下の異物摘出のための処固 でもあるが，この造影剤が肺組織に与える影響につい ては末だ確認されていない。他の造影剤による場合と の比較も併せて今後の検討が必要であると思われる。

次に最近 Xercradicgraphy, Xerotomography によ る気道異物診断法 ${ }^{6)}$ が発表された。乳房その他の軟部 のX線診断に好成績を示している検査法だが，気道異 物の診断法としてはなお今後の検討を要するものと思 j。

\section{3. 治 療}

気道異物に自然喀出の例がないわけではない。しか し盲端に終る気道に異物が侵入した場合には，それを 摘出する以外には治療法はない。

1）局麻か全麻加

麻酔に関する最近の内外文献をみると殆んどが全麻 についての報告である。殊に Ventilating bronchos. copy に関する麻酔が主となっている。また個々の症 例報告をみても，この Ventilating bronchcscopy（以 下 V. B と略す）による全麻下の摘出が急増してい る。ところがその中に，「全麻の気管 (支) 鏡検査を禁 忌とした Jackson 時代の矛盾は当時の吸入麻酔法の 末熟さからきたものと解釈される」とした報告》があ る。

C. Jackson は1934年発刊の著書に彼の工夫考案に よる酸素や麻酔荗を吹入れるための副管を装着した気 管支直達鏡, 乳児用 $(4 \mathrm{~mm} \times 30 \mathrm{~cm})$, 小览用 $(5$ 
$\mathrm{mm} \times 30 \mathrm{~cm})$ ，小児大型 $(6 \mathrm{~mm} \times 35 \mathrm{~cm})$ を記載 し, その用途について註記している ${ }^{8)}$ 。この副管をつけた 直達鏡は，現在の V.B の側管式と殆んど変りのない ものである。それなのに Jackson は乳児の直達鏡検查 を無麻酔下に行い，全麻を禁忌とした，その矛盾は麻 醉法の未熟さからきたものだ，というのである。

Jackson 時代，すなわち 40 50年前は，全麻といえ ば危険なクロロホルムを使用していた時代だが，呼吸 障害のある乳児の直達鏡検查をクロロホルムを使って 全麻下に行うことは，それ自体が危険であった時代な のである。しかし，それでも異物は摘出しなければな らない。そこで無麻酔下に手早く直達鏡を捙入し異物 を摘出し，乳児を死より救っていたのである。決して 矛盾でもなければ麻酔法の未熟さによるものでもな 以。

温故知新, 先達の苦心や識見を謙虚に, 正しく理解 し,これからの発展の資とするょう心掛けたいもので ある。

2）上気管支鏡法加下気管支鏡法加

従来なら下気管支鏡下に摘出していたであろう異物 症例の中には，全麻下，V.B で上気管支鏡下に安全 に摘出できる症例が増えていることは確かである。し かし V.B による異物摘出報告の中に, 套管抜去困難 を伴らから気管切開を避け， V.B による上気法を行 うとの報告や，「下気管 (支) 鏡検査とは局麻または無 麻醉で気管（支）鏡検查を行わざるをえなかった過去 の時代の方法であり，内容的には粗暴な方法である。 もはや下気管（支）鏡検査は原則的に廃棄すべき時期 にきていることを強調しておく」との報告》がある。 套管抜去困難症は気管切開技術に関する問題である。 また気管切開の適応が拡大され異物以外の疾患に対 し, 患者の生命を救い維持するために, 随時施行され ている現在, 何故, 気管切開下の気道異物摘出法を粗 暴な方法といらのであろらか，その判定が僅か 5 例の 経験からの結論のようなので，ここに敢て取上げるほ どのことではないかも知れない。しかし他にも「下気 管支鏡下の摘出は考えられないか」との質疑に「気管 切開は避ける。V.B で摘れなければ開胸して摘出す る」と答えている症例報告もあるのでここに一言せざ るを得ない。

気道異物には気管切開をして下気管支鏡下に摘出し なければ摘れない症例がある。また患者の全身管理 上，予め気管切開を施し，下気管支鏡下に摘出した方 が安全であり，またそうしなければ異物は摘出したが 予後不良という症例もあることを知るべきである。
下気管支鏡下の異物摘出は決して過去の時代の方法 でもなければ，内容的にも粗暴な方法でもないのであ る。まして廃棄すべき時期にきているなどとは全くの 独断である。上気管支鏡法か，下気管支鏡法かについ ては，山本 ${ }^{9}$ ，浅野10)，その他の報告がある。

3） Fiberscope による摘出法

細くて長い気管支直達鏡の中に銝子を挿入し，異物 を適確に把握し，摘出するには経験と技術を要する場 合が多い。しかし Fiberscope で異物を真近かにみな がら, 鉗子や鈎その他の特殊器具を操作し, 異物を把 握し，摘出することは比較的簡単で安全にできる。

池田 ${ }^{11}$ は flexible Bronchofiberscope で末梢気管支 に深く嵌入していた魚骨異物を摘出しているが，使用 鉗子の改良，考案を必要とすると述べている。硬性直 達鏡でみることのできない深部の異物摘出には用いら れる方法 ${ }^{122}$ である。私は硬性直達鏡でみうる範囲の気 管支異物は，直達鏡管内に硬性の Fiberscope を挿入 し，異物を真近かにみて，従来の摘出鉗子やその他の 器具を操作して摘出している。右気管支に隙間なく嵌 入し，鉗子ではつかむことができなかったプラスチッ クの笛の筒，左上葉気管支腔に埋っていた金冠，既に 肉芽に掩われていたパチンコの玉など，摘出困難で送 院されてきた症例も，この方法で摘出に成功してい る。その実態は内視鏡映画に記録し13)，学会に発表し 供覧したが，この方法は今後，普及，活用されるもの と考えている。乳児用気管支直達鏡に Fiberscc pe を 装着した斎藤 (成)の考案もその一つの現われである。

4） X線透視下の摘出法

気道異物をX線透視下にみながらの摘出は，針異物 の症例報告に多い。針の近端を鉗子でつかむことがで きれば，そのまま針を直達鏡管内に引きこんで摘出で きるが，針先が気管支壁に刺さり，横になっていると その摘出は容易でない。針を回転鉗子でつかみ，直達 鏡管内に折り曲げるようにして引き込み摘出した報告 も ${ }^{14)}$ ある。新らしい針なら折れずに曲って摘れる製品 が多いという。Tucker のピン鉗子を用いれば，横に なっている針も，その向きを鉗子の軸に一致させ，直 達鏡管内に容易にひきいれることができる。その他， Staple や安全ピンなじ，その摘出に特殊鉗子を必要と する場合があるので，平素その使用法に慣れておけ ば，X線透視下の操作も容易となる ${ }^{13)}$ 。

なお，針異物がその摘出操作中に咳とともに飛び出 してきて，術者の眼鏡や有に当って床に落ちた実例も 報告されているので, 術者は必ず眼鏡か顔面保護器を つけるよう, 特に注意しなければならない。 
$\mathrm{X}$ 線透過性異物を $\mathrm{X}$ 線透視下に摘出する場合は，造 影剂が異物の介在部位, 形，大きさなどを明らかにし てから摘出する。造影剂には, それぞれ得失があっ て, どの造影剤を用いるかは，その都度，検討を要す るが，乳児の場合には造影剂そのものが残って異物様 の障害を起こすことのないよう特に配虑する。

5）その他の摘出法

以上の他に, 気道異物の摘出にはいろいろと工夫が こらされている。吸引法もその一つである。乳幼児の 末梢気管支に嵌入したピーナッツ小片は, 鉗子では容 易につかめず，反って深部に押しこんでしまうことす らある。Fiberscope や造影剤でその位置を確認した ら，そこに吸引管の先端にネラトンカテーテルの一部 をはめこんだものを近付け, 強く吸引するとピーナッ ツの小片は吸引管の先に吸いついてくる ${ }^{13)}$ 。気管支分 泌物も吸引排除できるので異物摘出後の経過も順調と なる。

その他, バルーンカテーテル13)15)や気管支検査用の ブラッシュを用いての摘出法などが報告されている。 しかし何れにせよ, 異物をしっかり把握しての摘出で ない限り，異物は再び落下し，また異物となる恐れが 多分にあることに留意し, 確実な方法で摘出するよう 心掛ける必要がある。

6) 救急処置

異物誤嶼と同時に呼吸因難, 窒息を来す喉頭入口部 つ閉塞の場合と, 先ず激しく咳込み, 呼吸因難となり 苦しみ, チアノーゼを呈する気管異物の場合とを鑑別 し，それぞれに適応した救急処置を行うことが必要で ある。ところが，その鑑別もしないで救急処置を行っ ている傾向がある。例えば, 突然呼吸因難となり, 窒 息状態となる喉頭入口部異物の場合には, 乳幼児なら 逆かさにつるし, 背中をたたき, 指を口腔深くつっこ み異物を搔き出したり, 嘔吐反射を起こさせる方法が 効を奏する場合がある。しかし異物が既に気管内に侵 人し, 舞踏性異物となり激しく咳込み, 呼吸因難とな っている乳幼児の場合には，これを逆かさにつるし， 背中をたたくと, 異物は声門下腔につかえ, 反って声 門を下から閉塞し，窒息を来寸恐れが多分にある。先 達の訓えるところであるが，その時には，うしろから 患児の上体を両脇で抱えてもち上げ，尻もちをつかせ るようにトントンと上体を上下させると，異物は左右 気管支の何れかに落ち込み，1側の気管支が開放さ れ, 呼吸ができるようになる。窒息の恐れが去った ら，それから直達鏡下に異物を摘出すればよい。この ように気道異物の介在部位によってその救急処置が違
らことに注目し, 改めて救急処置を検討し, 適確な方 法の周知をはかる必要がある ${ }^{16)}$ 。

4. その他

1）特異な異物

アミノ化合物の結晶, 気管結石 ${ }^{17)}$, アクチノミコー ゼと肉芽塊 ${ }^{18)}$, 水銀, PTP などの気道異物報告の他 に, 金属異物による肺癌, 気管支異物が発見された肺 癌などの例がある。私も肺癌としての術前気管支鏡検 査で, それが異物による炎症性病変であった例を経験 している。

2）気道異物死亡例

餅, おしゃぶりの柄, ゴム風船, 看過された歯, 栗 の皮などによる死亡例，異物による突然死の報 告な ど ${ }^{1920)}$, その経緯には貴重な教訓として日常臨床, 緊 急処置に活かしたいものがある。

\section{おわりに}

気道異物の文献, 症例報告を通覧して思うことは, 異物事故防止に学会をはじめとし, 関係者が努力して いるにも拘らず，異物事故が相変らず起きていること である。ピーナッツを誤與した幼児の母親は，ピーナ ッツが気道異物になり易いことは知っている。しか し，まさか自分の子供が誤㫶しようとは思わなかった といら。他人事と思い, 注意す心゙きことを注意してな いためである。

同じようなことが医師側にも起きている。医原性異 物の報告が意外に多く, 問題となるのもその一つの現 れである。内視鏡検査件数の增加によるであろうが, 医師自身が検查時あるいは治療時に守るべきことを守 ってないための事故である場合が多いようである。

気道異物の診断, 治療についても同じことが言え る。また異物鉗子についても，その使い方も正確には 知らず, 特殊鉗子などみたこともない, 鉗子が $1 \sim 2$ 本あれば，異物は摘出できる，と思っている。ピーナ ッツを鉗子でつかんだものの大きくて気管支鏡管を通 して引き出せないので, 砕いて小さくして摘出すると いう。三位一体, 直達鏡, 鉗子そして異物を一体とし て取り出すことも知らないで異物を摘出している報告 もみられる。極く一部でのことであろうが，看過でき ない，基本を無視した最近の傾向として，ここにつけ 加えておきたい。なお論及す心゙き幾多の事項を残して いるが，紙面の都合もあり，おわりとする。 （文献その他に慈大耳鼻科教室員大戸武久君の協力を 得たことを記して感謝する。） 


\section{参 考 文 献}

1) 川添太郎他：気道内異物摘出 術の麻 酔, 麻醉, $21 ; 596 \sim 597,1972$.

2 ）広戸幾一郎他: Holzknecht 症候を呈さなかった 気管支異物，耳鼻と臨床，20；85，1974

3 ) Holzknecht, G.: Ein neues radioscopisches Symptom bei Bronchialstenose und Methodisches, WIENER KLINISCHE RUNDSCHAU, 13 ; 785787,1899

4) Kassay, D.: Observations on One Hundred Cases of Bronchial Foreign Body. Arch. of Otolayng. $71 ; 52-68$.

5 ）斎藤成司他：ピーナッツ異物の新らしい摘出法の 試み, 日気食会報, $23 ; 367-370 ， 1972$.

6 ) Doust, B.D. et al.: Detection of aspirated foreign bodies, RADIOLOGY, III ; 725-727.

7 ) 木村照：全身麻酔下の気管 (支) 鏡検查 (Ventilating Bronchoscopy) について, 耳鼻臨床，68；323 330,1976

8 ) Jackson, C. (小野譲訳) : 気管食道科診療の実際 学術書院, 1950.

9 ）山本馨他：気管支異物摘出と上および下気管支 鏡，日気食会報，23；164-168，1972.

10）浅野尚他：幼小児の気管および気管支異物の問題 点, 日気食会報, $24 ; 40-48,1973$.

11）池田茂人他：フレキシブル気管支ファイバースコ ープによる気管支異物摘出の 2 例, 日 気食会報, 24 ; 216-217, 1973.
12) Zavala, D.C. et al.: Experimental removal of foreign bodies by fiberotic bronchoscopy, AMER. REV. RESP. Dis, 110 ; 357-360.

13）滝野賢一：内視鏡映画による気管食道直達鏡所見 の検討(9), 気道異物摘出法について，（映画） 1975.

14）浅輸薁：陳旧性気管支異物（待針）の 2 症例とそ の摘出法，日耳鼻会報，74；1588，1971.

15) Bonfils Roberts E.A.: Balloon cathefer for endoscopic removal of foreign bodies. ANN. THO RAC. SURG. 19 ; 196-197.

16) Lange, G.: Immediate treatment of foreign bodies in the air passages and oesophagus, Z. LAR YNG. RHINOL, $52 ; 331-339$.

17) Penta, A.Q.: The successful removal of intra bronchial foreign bodies. Two cases. ANN. OTO LARYING. 87 ; 645-649.

18）田島玄：陳旧性気管支異物の一治 験 例, 日医事 新, $2430 ; 31-34,1970$.

19）立木孝：異物致死例，その対 策，日気食会報， $24 ; 221,1973$.

20) Steichen, F.M. et al.: Acute foreign body. laryngotracheal obstruction: a cause for sudden and unexpected death in children. Paediatrics, $48 ; 281-285$.

その他，146件

(別刷請求：干104 東京都中央区明石町10-1 聖路加国際病院気管食道科

\section{選択的気管支造影カテーテル FBS-6}

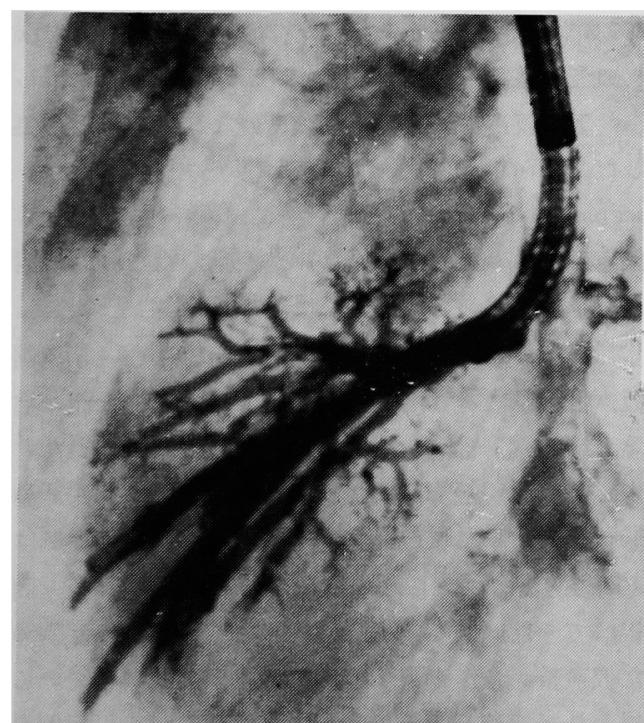

MACHIDA

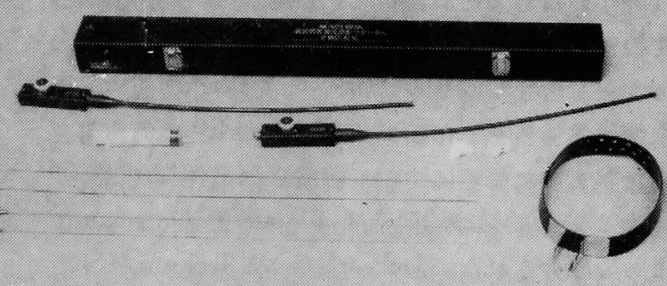

気管支ファイバースコープ "F B S" の パイオニアである当社が、胸部疾患の気管 支造影診断の重要性に着目し、新しい観点 から開発した総合的な気管支造影専用力テ ーテルです。

\section{禁攀田田䍩作所}

営業部 東京都文京区本駒込5-10-8 个113 電話 東京（03）827-5231 代表 